\title{
Trend of Informality in the Meat Product
}

\author{
Msc.Raimonda Ajdini Ph.D Henerieta Themelko Msc. Ilir Ajdini \\ raimonda.ajdini@gmail.com \\ P.G. Student, Department of Economy and Agribusiness, Agricultural University of Tirana, Tirane, Albania \\ Assistant Professor, Department of Economy and Agribusiness, Agricultural University of Tirana, Tirane, \\ Albania
}

\begin{abstract}
Slaughterhouses are an important element in the management of meat product in Albania, such as the study on the functioning of their form is very necessary, we decided to analyze the steps pose passing meat product in Albania. As meat is a very important component of the Albanians diet, this study is based on data of customers for the product meat. We will treat terms of product quality meat that is, the standards applied in the marketing of this product. To reach these objectives, this study designed a conjoint choice experiment survey and collected primary data in the most populated cities of Albania. The meat industry and its marketers may benefit from this information by using it to strategically market their meat to different groups.

This study refers to the informality that occurs mainly in meat products in Albania, especially for the district of Tirana, specifically the Tirana-Kavaja area.

The study will encourage meat shops or slaughterhouses not to be part of the informality that we slaughter until the sale to the consumer. The relevance of the research lies in the way the meat product is traded.
\end{abstract}

Keywords: P.G. Student, Department of Economy and Agribusiness , Agricultural University of Tirana, Tirane,Albania Assistant Professor, Department of Economy and Agribusiness , Agricultural University of Tirana, Tirane,Albania

\section{INTRODUCTION}

Albania has been, is, and will remain for years a country where agriculture will play a very important role. Currently agriculture makes up about 31\% of GDP (MoAFCP 2012). Therefore it is important to consider agriculture in any of the country's strategic planning. Despite the importance of agriculture for the national economy, Albania is a net importer of agricultural products. The ratio of exports to imports in total is $1: 8$, with the value of total import of meat products in 2012 at 15,900,890 Euros (MoAFCP 2015).

However, in the process of approximation to the European Union (EU), Albania seeks potential export opportunities to EU and international food markets. Meat is among the traditionally produced agricultural goods in Albania. The dairy industry, and along with it meat collection system, are still in the course of modernizing structures and technologies. In the late 1990s, the first private slaughterhouses plants were established in different regions of the country. 
MANAGEMENT , ECONOMICS AND HUMANITIES

July 23-25 2021

Stockholm, Sweden

Businesses operating in informality are able to avoid taxes and rules but suffer from the inability to effectively enforce contracts (as the business is operating illegally) and may give up formal lending markets.

While it is clear that this phenomenon exists, a standard definition of the informal sector is not found in the literature. However, there are numerous definitions used in different studies.

I would use the definition (Feige, 1990), according to which an activity is considered to be part of the informal economy or informal sector if this activity does not "comply with the established rules" present in the formal economy.

This means that the informal economy can only be defined in a particular context of the institutional structure surrounding it.

In recent years, scholars have shown interest in studying informal economy in many countries. This has come as a result of the causes and implications of policies related to the informal economy. Informal economy is difficult to measure because in nature it is a hidden economy. Macroeconomic methods help to calculate this part of the economy indirectly.

The authors (Schrage, 1984) and Thomas (1992) have defined the informal economy as "A set of activities that are legally subjected to taxation but are not declared as commercial legal activities and are not included in the value of national income or that are partially included in GDP "

In the literature of recent years and the IMF, the definition is accepted that in economies that are involved in bribery and corruption, economic initiatives are distorted as officials, governors, and private individuals are deferred to pay smaller portions of public spending from which public good is offered.

Consequently, the government collects fewer revenues that lead to lower public investment and increase the poverty and inequality of citizens.

It has always been assumed that the informal sector existed but was not deliberately studied until 1970 when economic events in the US and Europe allowed the researchers to consider how uneconomic economic activity is. Since then, the informal economy has been in the hands of economists, but relatively little progress has been made in its understanding. The importance of the informal sector lies mainly in its potential impact on economic policy.

Policy makers have little choice, they have to believe that the economic measurements and statistics provided to them by economists are accurate and the policies are formulated in this way on the basis of this information.

However, the informal sector potentially undermines the accuracy of this information, as informal economic activity, by definition, is not included in traditional economic indicators, and may therefore lead policymakers to make the wrong decisions. 
MANAGEMENT , ECONOMICS AND HUMANITIES

July 23-25 2021

Stockholm, Sweden

Understanding the factors which may significantly influence household consumption is important in the planning of slaughterhouses, processors and manufacturers. Consumers' responses to changes in price and non-price factors are basic to an economic analysis of almost all the policy decisions related to industry or government programs. Forecasting the future direction of household consumption, and how that direction might be modified through industry efforts or by national programs and policies, requires information on the relationships among prices, incomes, household characteristics and consumer demand. This study focuses on households as consuming units, explains and analyzes their purchasing behavior for dairy products.

The aim of this study is whether Albania has overtaken slaughters that meet European standards, as is the amount of trade of meat products in Albania. In other words the study tries to find out how different slaughters consider different attributes of meat, when they buy the product. From these differences we can than determine the market segmentation toward this.

\section{SIGNIFICANCE OF THE SYSTEM}

The paper mainly focuses on identifying the current situation in the meat industry in the region of Tirana,identifying factors influencing informality referring to categories, Farmers / Breeders, meat / slaughter industry, consumers, makers. The study of literature survey is presented in section III, Methodology is explained in section IV, section V covers the experimental results of the study, and section VI discusses the future study and Conclusion.

\section{LITERATURE SURVEY}

Tirana Region lies in the central part of Albania at an altitude ranging from several meters above sea level up to 1828 meters. the highest peak is represented by mountain . The county has an area of $1,654.63 \mathrm{~km}^{2}$. In its western part there is a coastal line with the Adriatic Sea. The length of the coast line is $33 \mathrm{~km}$, while in the north it is bordered by the district of Durres, northeast with Dibra, southeast of Elbasan, and in the south by the district of Fier.

The Tirana District Relief is a diversified combination of mountainous areas with lowland areas and coastal areas. There are some rivers and lakes in Tirana's territory. The main rivers that describe the territory of the region are the Erzen, Iege, Shkumbin and Tirana River River, which also describes the city of Tirana with its branch called Lana River. In Tirana, the lakes are artificially man-made: the artificial lake of Tirana, Lake Kodër-Kamëz, Farkë Lake, Tufina Lake. Lakes and rivers create a diverse landscape and constitute a potential for recreational and recreational facilities.

Tirana Region consists of two districts, Tirana and Kavaja districts. In the district of Tirana there are three municipalities of Tirana Municipality, Municipality of Vores, Kamza Municipality and Kavaja District have two municipalities of Kavaja Municipality and Municipality of Rrogozhina. In the district of Tirana there are 29 administrative units. The average altitude of the Tirana field is $521 \mathrm{~m}$, while the two highest mountains on which to lie are Dajti Mountain 1612 m and Mali me Gropa with 1828 m. 


\title{
MANAGEMENT , ECONOMICS AND HUMANITIES
}

July 23-25 2021

\author{
Stockholm, Sweden
}

Commercial entities or natural persons, because of their limited commercial activity, do not make cash payments for the circulation of their goods or services. These payments are regularly made through the second tier banks in the Republic of Albania, documenting all their receipts and / or payments.

Under these conditions, these businesses issue regular tax invoices (VAT format or simple tax invoice) but have not installed fiscal equipment, in accordance with the provisions of Article 55 of Law No. 9920 dated 19 May 2008 (as amended), which provides for the general rule in paragraph 1 as follows: "Taxpayers who conduct the flow of goods and services for which payments are not made through the bank are obliged to install and use the fiscal system through the use of fiscal equipment for registration of cash payments and for the obligatory issuance of a tax coupon ... "and following the legal details set forth in the Instruction of the Minister of Finance no. 24 dated 02.09.2008 "On Tax Procedures" (as amended)Send feedback, History, Saved, Community.

This study does not pretend to exhaust all the issues on causes and measures for dealing with informality. It aims to stimulate debate and pave the way for other studies and prioritize concrete business-generated recommendations aimed at improving the business climate and enhancing fair competition.

As a result of the increase in the number of livestock and poultry feeders for the production of meat product, a chaotic situation has been created requiring a reorganization of public structures across the chain from livestock breeding to the concentration of live animal markets - livestock trading, transport, slaughter, reimbursement scheme / farmer sales scheme, standardization and categorization of slaughtered carcasses, collection of purchase price and meat sales as a result of promotion of the whole chain for the declaring of the number of the animals increased their matriculation and slaughter procedures through a reimbursement scheme that formalizes the animal and slaughter market and after the conditions of meat trade, guaranteeing the traceability, identification and regionalization through the farmer's farmer and the area.

\section{IV.METHODOLOGY}

Based on the data gathered from this study as well as to make a realistic and comparative analysis

In order to realize the objectives and hypotheses of this study, we will collect information through face-to-face customer surveys of meat products.

Use of statistical models of emerging variables among variables of interest.

Descriptive analysis of the processing industry sector based on primary and secondary data. 
Its main exhibits and descriptions

A sample size of 200 questionnaires made with customers of meat products in Tirana and Kavaja is considered a suitable size to provide reliable and reliable data for the meat product informality analysis. Interviews were conducted personally by myself, by occasional customers. Our questionnaire is mainly conducted in two areas, Tirana which includes (agricultural institute, block area, unit 11, Kashar and Durrës road) as well as the circle of Kavaja, from where customers were selected to study our (sample). The data obtained in the tables below shows the descriptive data regarding the Albanian consumers' considerations of meat product informality and the modeling related to our sample.

Unsubscribed surveys to:

The breeding / farmer / commercial / thorax / meadow breeding actors part of the fresh meat producer chain in the region of Tirana will receive an answer on the above hypotheses.

The most important zinc chain of meat production and trade in the district of Tirana are:

a. Producers / Farmers who, according to the data of 2017, by the Regional Agriculture Directorate in Tirana Region (who have set a limit for potential farmers who have less than 8 cows, not less than 150 sheep or goats, no less than 10 dosa) where the total of these farmer / breeder is:

- Comprehensive Farmers 199, of which we intend to poll $50+1 \%$ through Type A Survey, equally divided into the administrative unit and the species of breeding species.

b. Slaughterhouses / Meat Trade Points that according to data from the National Food Authority, Tirana Regional Directorate (which have specific requirements for the licensing of these business operators) where the total of these operators is:

- 16 Sheets (of which we intend to survey all)

- 285 points of meat trade we aim to poll $50+1 \%$ ) for both categories will be the same survey, type B survey.

c. Consumers (No fewer than 300 customers) when we expect them to get answers to the overall knowledge about food safety and the selection of the food product Fresh safe meat through type $\mathrm{C}$ survey.

\section{EXPERIMENTAL RESULTS}

Table 1and Graf 1,2, shows the data of individuals interviewed regarding meat consumption by dividing them according to their sex and residence where they live. In the first area for the women's category we have: 1 woman consuming $2 \mathrm{~kg}$ of meat per month, 16 consuming $4 \mathrm{~kg}$ of meat per month and 4 consuming $7 \mathrm{~kg}$ of meat per month. While for men we have 9 who consume $4 \mathrm{~kg}$ of meat per month and 23 who consume $7 \mathrm{~kg}$ of meat per month. In the second zone for the category of women we have: 13 consuming $2 \mathrm{~kg}$ of meat per month, 59 consuming $4 \mathrm{~kg}$ of meat per month and 16 consuming $7 \mathrm{~kg}$ of meat per month. While for males we have: 11 individuals men consuming $2 \mathrm{~kg}$ of meat per month, 44 consuming $4 \mathrm{~kg}$ of meat a month and 4 consuming $7 \mathrm{~kg}$ of meat per month. 
MANAGEMENT , ECONOMICS AND HUMANITIES

July 23-25 2021

Stockholm, Sweden

Show by place of residence, sex and consumption of meat product

\begin{tabular}{|c|c|c|c|c|}
\hline & \multicolumn{3}{|c|}{$\begin{array}{l}\text { Consumption } \\
\text { of meat } \\
\text { product }\end{array}$} & \multirow[b]{2}{*}{ Total } \\
\hline & $\begin{array}{l} \\
\mathrm{kg} \\
\end{array}$ & $\begin{array}{l}4 \\
\mathrm{~kg} \\
\end{array}$ & $\begin{array}{l}7 \\
\mathrm{~kg} \\
\end{array}$ & \\
\hline $\begin{array}{l}\text { Location } \\
1\end{array}$ & 1 & 25 & 27 & 53 \\
\hline Females & 1 & 16 & 4 & 21 \\
\hline Men & & 9 & 23 & 32 \\
\hline $\begin{array}{l}\text { Location } \\
2\end{array}$ & 24 & 103 & 20 & 147 \\
\hline Females & 13 & 59 & 16 & 88 \\
\hline Men & 11 & 44 & 4 & 59 \\
\hline Total & 25 & 128 & 47 & 200 \\
\hline
\end{tabular}

Table 1

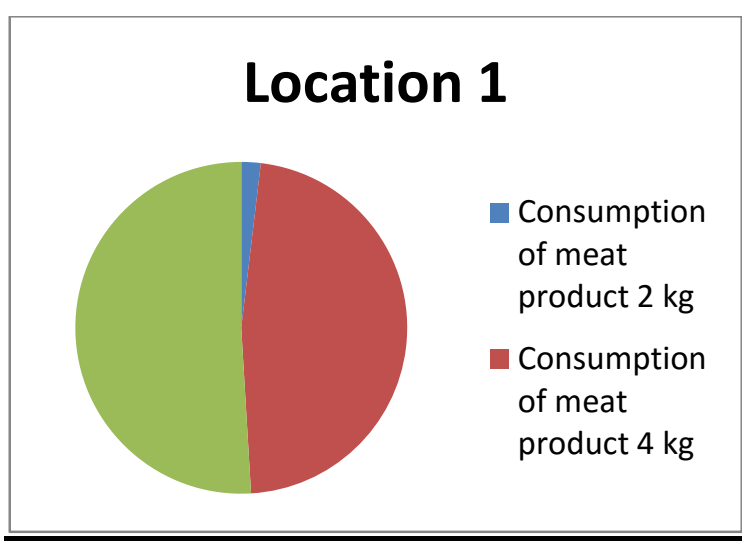

Graf 1

The above data represent the trend of informality for the meat product by estimating it from 0 to 4 . We notice from interviewed individuals that 1 is 0 agree, 56 of respondents agree with indicator 1 that there is informality in the meat product, 87 interviewees estimate with 2, 44 have evaluated with 3 informality and 12 interviewed have evaluated with 4 informality of the product of meat by 200 interviewed in total.

Trend of informality in the meat product

\begin{tabular}{|l|l|}
\hline Agree & $\begin{array}{l}\text { Number of } \\
\text { interviewed } \\
\text { customers }\end{array}$ \\
\hline 0 & 1 \\
\hline 1 & 56 \\
\hline 2 & 87 \\
\hline 3 & 44 \\
\hline 4 & 12 \\
\hline Totali & $\mathbf{2 0 0}$ \\
\hline
\end{tabular}

Table 2

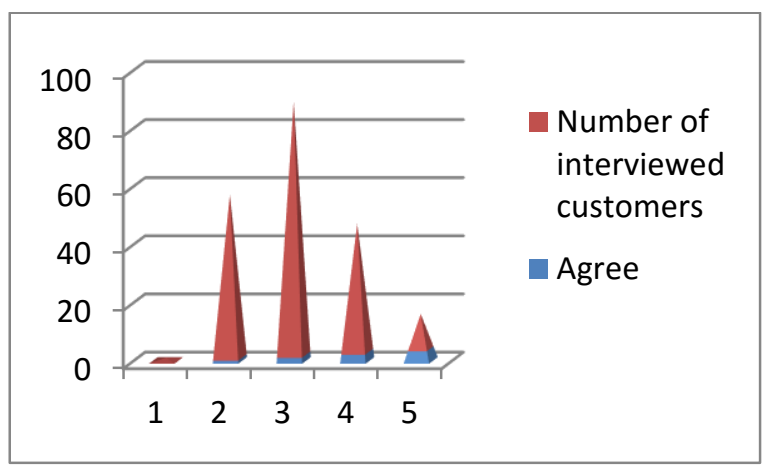

Graf 3 
MANAGEMENT , ECONOMICS AND HUMANITIES

July 23-25 2021

Stockholm, Sweden

\section{CONCLUSION AND FUTURE WORK}

Dairy activities have a long tradition in Albania due to the favorable natural resources for dairy production.

Farmers / Small Animal Suppliers are not interested in formalizing or declaring adult animals as the reimbursement scheme for them is without inters or does not stimulate them to matriculate, so they are not interested in paying more taxes to the state or cost additional to bureaucratic procedures.

Bigger farms have matriculated and follow all the procedures for associability with food and food safety standards, but they find it difficult on the market because they have high costs for bureaucratic procedures and the reimbursement scheme is too small for more dishonest competition of farmers / small prize winners come at a much lower price because they do not have these bureaucratic costs.

Licensed Slaughterhouses declare that the purchase price of live cafes is far more expensive slaughter procedures the fulfillment of the conditions and food safety standards drastically increases costs by taking into account:

- Non conformities (non-healthy animals) go for disposal

- Maintaining the product during the staging of expected losses,

Compared to slaughter in informal areas, which buy unmarked bears with lower prices are slaughtered without meeting the conditions and food safety standards have not spilled because they do not stab the meat according to the slaughter procedures, do not have electricity costs because they do not store they do not have costs for bureaucratic procedures. They sell hot meat and promote unrestrained competition by selling at a much lower price.

Licensed slaughterhouses are part of the chain, but are not the last link that belongs to the grower afterwards. The slaughtered meat goes to the Fresh Meat Shops Shop.

Fresh meat or fresh meat shops are a chain link that has emerged recently, following the intervention of the controlling structures (the national food authority) for the slaughter of slaughterhouses in trading environments and this part of the chain is what it has direct contact with the customer.

From the survey in this section of the chain emerge the following facts:

This part is also affected by informality from drops that sell and sell hot meat informally or secretively as the price in this part of the chain increases even more as a result of the bureaucratic storage conditions (firo) of the bureaucratic procedures such as the HACCP manual (implementation of the manual of critical checkpoints analysis) as well as the tax procedures.

Data from consumer habits / preferences (referred to as a questionnaire)

$87 \%$ of the humans trust the butcher they know. 


\title{
MANAGEMENT , ECONOMICS AND HUMANITIES
}

July 23-25 2021

\author{
Stockholm, Sweden
}

$80 \%$ of Customers want to buy hot meat and want to be present during slaughter.

$68 \%$ of customers do not have the idea of veterinary certify or do not see it at all.

$72 \%$ of customers do not read the label in table which has the legal obligation as animal of the animal the number of the stamp date of slaughter etc.

$63 \%$ of consumers are not sensitive to the conditions that must meet a meat-selling point they want to touch the meat to see close and them want to wait for themselves.

$90 \%$ of consumers are not at all interested in the tax coupon.

$90 \%$ are more interested in the price of meat compared to quality and safety and hygiene and sanitation standards.

Meat producers must meet consumers' demand for meat when there is demand in order to remain competitive.

Once we are able to clearly describe the existing demand for meat, a marketing strategy can be properly developed. In the meat industry remains the most important component in terms of production and also in consumption.

\section{REFERENCES}

- Ministry of Agriculture, Rural Development and Water Administration, www.bujqesia.gov.al

- Directorate of Agriculture Food and Consumer Protection

- Regional Agencies of the Ministry of Agriculture

- National Food Authority

- Veterinary Research Institute

- Agricultural University of Tirana Department Technology and Food

- University of Tirana Faculty of Natural Sciences 